\title{
RESEARCH ON COMPETENCIES OF LOGISTICS SPECIALISTS IN TRANSPORT ORGANISATIONS
}

\author{
Aušra KATINIENE் ${ }^{1}$, Živilè JEZERSKE் ${ }^{2}$, Kristina VAIČIŪTE் $3^{3}$ \\ ${ }^{1}$ Department of Information Systems, Vilnius Gediminas Technical University, Vilnius, Lithuania \\ ${ }^{2}$ Department of Management, Vilnius Gediminas Technical University, Vilnius, Lithuania \\ ${ }^{3}$ Department of Logistics and Transport Management, \\ Vilnius Gediminas Technical University, Vilnius, Lithuania
}

Received 31 March 2020; accepted 12 March 2021

\begin{abstract}
Successful activities of logistics specialists in transport organisations depend on their ability to adapt to a rapidly changing environment where the most changing and essential element - knowledge - is the most important constituent of competence. The lack of competencies of logistics specialists employed in transport organisations and the inconsistencies with the timely use of such competencies decrease the efficiency of performed functions and slow down organizational processes. As the result, employers are forced to deal with an alternative problem, i.e. whether to invest in inexperienced young logistics specialists for them to acquire competencies or to replace them with more experienced specialists. The article analyses the peculiarities of the competencies of logistics specialists and their use as a tool to ensure the development of logistics organisations and the quality of logistics services. The carried out qualitative research enabled the identification of the competence problems of logistics specialists - logistics manager and logistics forwarder - in transport organisations.
\end{abstract}

Keywords: logistics specialists, transport organisations, competencies, criteria, expert ranking, evaluation.

JEL Classification: M12, M51.

\section{Introduction}

Fierce competition in today's transportation market has caused a rapid and diverse evolution of transport companies, related to managerial skills of logistics specialists. It is of great importance for an organization operating in the global market to effectively manage the existing, or potentially available, labour resources, and to sustain previous successful performance (Tan et al., 2007; Wu et al., 2010; Martin, 2011) that results in the use of resources and practices that enable the implementation of efficient activities (Paiva, 2017). According

\footnotetext{
${ }^{\star}$ Corresponding author. E-mail: kristina.vaiciute@vilniustech.lt
} 
to Palšaitis et al. (2016), Chlivickas et al. (2009), professionalism, skills and flexibility of the logistics employees at logistics and transport companies are of particular importance in the opinion of service users, as logistics specialists comprise a constituent element in the process of service creation, provision and consumption; and that particular element reflects the demand of clients, as well as the representation of the service quality. Scientific research by Harreld et al. (2007), Ledauskaite (2010), Palšaitis et al. (2016) and Vaičiūtè et al. (2017) all the time emphasized the importance of the competencies of logistics specialists and how important they are for transport organizations. Logistics specialists are involved in various problem-solving processes, therefore, inconsistencies between the competencies of a logistics specialist in a transport company, and the competencies required to deal with various issues or professionally perform the functions, such as planning of logistics services, organizing and controlling their performance and execution, occur regularly.

Object of the Article:

The competencies of logistics specialists in transport organizations.

Objective of the Article:

To research the competencies of logistics specialists through a thorough analysis of the concepts of these competencies.

Goals of the Article:

To present the concept of the competencies of logistics specialists.

To analyze the competencies of logistics specialists in the form of a scientific problem analyzis.

To research the use of the competencies of logistics specialists, as a tool to ensure the quality of services provided by transport organizations.

Relevance and novelty of the topic:

Based on scientific literature, the article reveals the significance of qualified logistics specialists, i.e., the key competitive advantage of an organization. It presents the analyzis of the competencies of logistics specialists as a scientific problem by defining these concepts, highlighting their importance and essence in respect of theoretical modelling and other methodological aspects.

\section{Concept and content of the competence of logistics specialists, i.e. logistics manager and forwarder}

The changes in the transport market oblige organizations to constantly review the competencies of the specialists employed, and to respond to entrepreneurial changes (Juodeikaite \& Fominienè, 2016). The analyzis of foreign scientific research (Ekhtiari et al., 2016; BesterfieldSacreet et al., 2016; Devi \& Goswami, 2014; Gutiérrez \& Guerrero, 2012) states that competencies are commonly viewed at as an entrepreneurial phenomenon, and researched from economic-business points of view.

Analyzing the competencies of organization specialists, scientists (Tūtlys et al., 2015; Melnikova \& Trakšelys, 2016; Kotzab et al., 2018; Zatta et al., 2019; Chan \& Luk, 2020) are still in disagreement concerning the content and scope of application. They make a distinction between the concepts of "competency" and "competence", stating, that "a competency" is a 
concept that defines the field of professional activity in which a person is competent, i.e., a description of work-related tasks or expected results; whereas, "a competence" is a concept that highlights aspects of human behavior associated with the performance of work and defines the main characteristics of the individual who has achieved, or is able to achieve, good performance results (Bondarenko et al., 2020).

Some authors claim that the term "competence" defines the generalization of knowledge. Others believe that a competence is just a certain way of activity enabling the achievement of the set objectives. Still others are convinced that competences constitute specific personal features intended to perform a certain assignment (Table 1).

Table 1. Competence definitions (compiled by the authors)

\begin{tabular}{|l|l|}
\hline \multicolumn{1}{|c|}{ Authors, year } & \multicolumn{1}{c|}{ Definition content } \\
\hline Abraham et al. (2001) & $\begin{array}{l}\text { A set of personal features, behavior and traits necessary for performing } \\
\text { successful assignment. }\end{array}$ \\
\hline Weinert (2001) & $\begin{array}{l}\text { The ability to apply the basic content-specific principles and methods in } \\
\text { practical situations. }\end{array}$ \\
\hline Martinkus et al. (2002) & $\begin{array}{l}\text { The adjustment of knowledge and skills, and the ability to apply them in } \\
\text { specific circumstances; the performance of managerial functions, taking } \\
\text { into account environmental and situational restrictions. }\end{array}$ \\
\hline Lamoureux (2008) & $\begin{array}{l}\text { A set of clearly defined skills, behavior and knowledge used to assess a } \\
\text { person. }\end{array}$ \\
\hline Morkvenas (2010) & $\begin{array}{l}\text { The knowledge of a particular sphere that enables to solve complex } \\
\text { problems in that sphere. }\end{array}$ \\
\hline $\begin{array}{l}\text { Erkutlu and Chafra } \\
\text { (2012) }\end{array}$ & $\begin{array}{l}\text { Personal initiative, future insights, abilities to respond to changes in } \\
\text { the environment, and to implement the necessary changes in personal } \\
\text { activities by applying new methods of activity. }\end{array}$ \\
\hline Tütlys et al. (2015) & $\begin{array}{l}\text { The totality of the abilities to perform a certain operation or task in a } \\
\text { realistic or simulated operational situation. }\end{array}$ \\
\hline $\begin{array}{l}\text { Melnikova and Trakšelys } \\
\text { (2016) }\end{array}$ & $\begin{array}{l}\text { Different essential abilities and skills, which, combined with values } \\
\text { and attitudes, comprise a holistic competence, i.e., the ability to assess } \\
\text { a new situation, to choose the most appropriate operational methods, } \\
\text { constantly integrate entrepreneurial and professional knowledge. }\end{array}$ \\
\hline Lim et al. (2020) & $\begin{array}{l}\text { Essential performance competencies are the skills required to fulfill the } \\
\text { assignments in the majority of the occupations; the concepts of these } \\
\text { core job competencies have been developed to reflect the needs of the } \\
\text { industry. }\end{array}$ \\
\hline
\end{tabular}

To summarize, it can be claimed that a competence is a set of personal applied abilities, skills and professional knowledge required to choose the necessary operational methods and to perform the activities/functions/work of a particular type.

The essence of a competence is determined by the level of the existing ability or qualification of a specialist, and the professional experience gained (Jovaiša et al., 2008). According to Martinkienè (2009); in order to perform the assigned task well, a logistics specialist must have certain functional abilities that are often referred to as professional competencies, enabling them to successfully carry out operational functions. In addition to significant emphasis on technical skills and knowledge, soft competencies are considered of importance, 
as well as competencies of continued learning, flexibility, creativity, problem-solving, critical and analytical thinking (Jerman et al., 2020). In the opinion of Ledauskaite (2010), a logistics specialist is a person educated in this sphere who has job-related competencies and is able to link all logistics operations, to optimize logistics expenses, to plan, manage and control information and material flows, and processes in space and in time, from the primary source to the end-user. According to Trivellas et al. (2015), Abraham et al. (2001), these general competencies are the most vital, as they act as a mediator between career success satisfaction and work-related outcomes. Zaychenko et al. (2019), Vaičiūtè et al. (2017), Palšaitis et al. (2016) emphasize that a logistics specialist has to possess certain functional abilities, i.e., professional competencies, to carry out the assigned work in a qualified way. Vaičiūte et al. (2017) state, that logistics specialists must have mastered professional competencies in their field. To summarize, and in accord with Zacharia et al. (2011), a logistics specialist is a person whose capabilities enhance the outcomes of the supply chain.

Understanding the possibilities of the competencies of logistics specialists and their involvement, comprises the assessment of the present and future service possibilities of a transport organization, and the investment in technologies that enable a company to gain a major competitive advantage in the market (Harreld et al., 2007; Wu et al., 2010). In the opinion of Armesh et al. (2014), Dobroszek et al. (2019), the competencies of specialists have an impact on the management of a technological environment, and the competitiveness of an organization.

Kilibarda et al. (2019), Bagaeva et al. (2019), López et al. (2019), European Logistics Association (2014), referring to the Center for the Development of Qualifications and Vocational Training (Kvalifikacijų ir profesinio mokymo plètros centras, 2015), state that a logistics manager must have and be well- versed in the following professional competencies: to evaluate the requests from clients; to plan the execution of orders; to control the process of order execution; to organize the loading and unloading of products; to store and control products; to manage the stocks, to organize the packaging and dispatching processes of the products; to plan, organize and control the material flows in an organization. A logistics forwarder shall have and be well- versed in the following professional competencies: to find potential clients and establish contacts; to identify the needs of the clients; to explain the offered logistics and transport services in a national and foreign languages; to make use of the office equipment in the activities; to accept, store and account for the goods; to prepare the criteria for the selection of suppliers; to prepare the criteria for the selection of means of transport; to prepare the criteria for the selection of freight; to select suitable transport for the carriage of the goods; to set optimal transportation route; to estimate the total transportation time, fuel consumption and route profit; to use geographical information systems; to use transport- tracking software; to manage logistical information systems; to use modern general information systems; to provide the information as to the issues related to traffic direction, the need for transport maintenance, transportation of goods and the related documentation; to submit the goods for customs' clearance and declaration.

Having analyzed the content of the competencies necessary for a logistics manager and logistics forwarder, the following three main competence groups can be distinguished which must be well- mastered: special competencies (to understand the principles of logistics and 
transport operations, i.e., the competencies required to fulfill the assignment); analytical competencies (the competencies needed to plan an optimal route, select cargo criteria, identify the needs of the clients, i.e., the competencies related to the analysis, synthesis, modeling methods); personal competencies (communication, cooperation with clients, i.e., self-management competencies) (Figure 1).

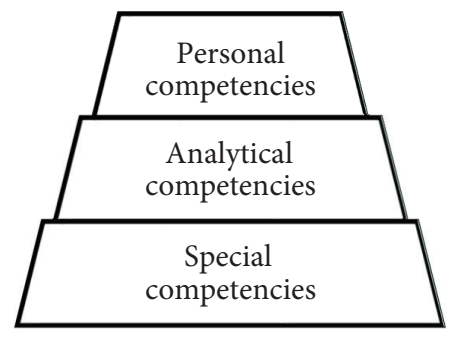

Figure 1. Competence groups of logistics specialists (compiled by the authors)

To summarize, it can be stated, that the competencies of a logistics specialist are linked with the ability to perform a specific task in the sphere of transport/logistics. Constant changes occur in the field of transportation, therefore, it is necessary to analyze which competencies should the logistics specialists working in such organizations develop, apart from being able to assess and identify the missing competencies.

\section{The research on the competencies of logistics specialists}

To assess the competencies of logistics specialists in transport organizations the algorithm consisting of four stages was designed (Figure 2). The first stage is designated for the preparation of a questionnaire.

In the second stage, experts are selected, based on certain criteria, who are then familiarized with the concepts of competences, which are further divided into the main groups of competencies: special competencies (competencies required for the work); social competencies (needed when working with people); personal competencies (self-management competencies).

In the third stage, the experts conduct a survey; the concordance of data matrixes and expert opinions is calculated based on the Kendall's coefficient of concordance. If the opinions are not concordant, the experts are questioned again; if the opinions are concordant, the fourth stage, data processing, begins.

In the fourth stage, the data is processed and the assessment results are presented to the organization. Based on such results, the board of the company can make decisions concerning further development of competencies of their employees related with the improvement of their qualification or the change in their career. These changes would lead the organization employees to performing the work more efficiently; their communication and cooperation would improve.

The research was carried out with the help of the ranking and questionnaire survey methods seeking to clarify the importance of the competencies of logistics specialists in transport organizations. 


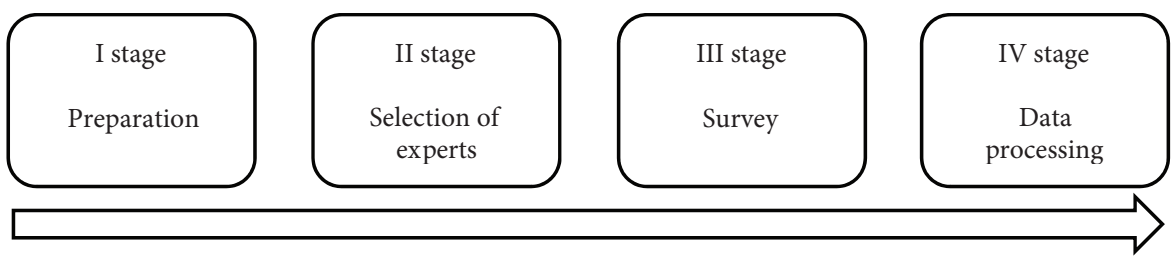

Figure 2. Research stages (compiled by the authors)

According to Sivilevičius (2011), Podvezko (2005), the applied multi-criteria evaluation method, i.e., $n$ selected experts evaluated $m$ indices by way of ranking. Ranking is a method, whereby the most important index is assigned as rank $R$, equals to one, the second equals to two, and the last equals to $m$ (where $m$ is the number of indices being compared).

The questionnaire method enabled the researchers to collect statistical material revealing the actual reality and its development trends; the dependence of certain phenomena on other phenomena, as well as their interaction. The questionnaire included the questions with programmed answers, thus, providing the respondents with the possibility to select the most suitable answer. To have representative questionnaire results, the target survey segment was established, i.e., 6 experts that matched the following criteria were questioned: education in the sphere of logistics or transport, at least a 5-year working experience in a transport organization, and at least a 3-year management experience.

Each expert was provided with individual competence tables and the instructions how to fill them in, definitions of competencies and a rating scale. In the instructions, the experts were asked to assess the competencies necessary for logistics specialists, a logistics manager and forwarder, and to rank them according to their importance (Podvezko, 2005). In case of necessity or doubt, the experts received consultation via online and mobile chat services.

The experts were asked to assess which competencies are the most important for a logistics managers working in a transport organization (1 as the most important, 11 as the least important) (Figure 3).

Table 2 shows the questionnaire survey results on the importance of the competencies of logistics managers indicated by six experts, and the key estimated values: total rank, mean rank, the difference between total rank and rank constant and the square of variable (Table 2).

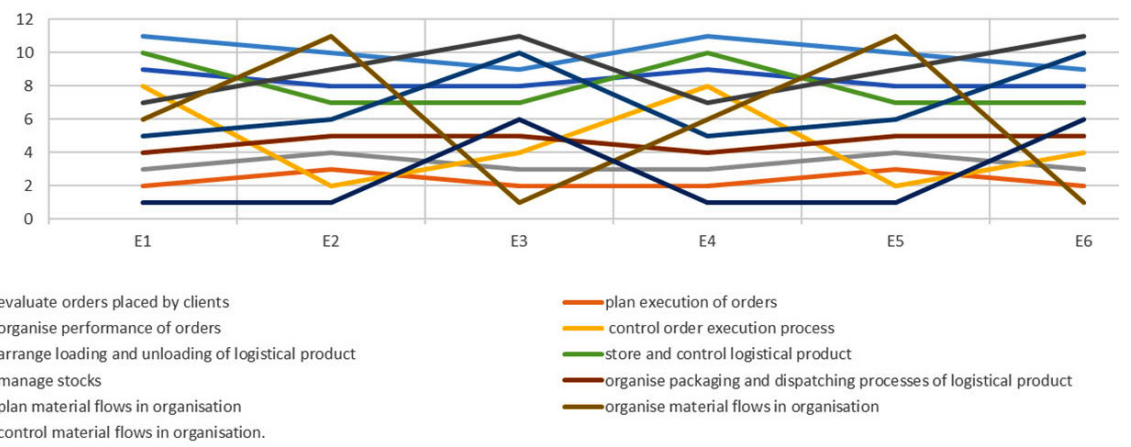

Figure 3. Distribution of expert ranking (compiled by the authors) 
Table 2. Summarizing indicators of competence assessment of logistics managers (compiled by the authors based on Sivilevičius, 2011)

\begin{tabular}{|c|c|c|c|c|c|c|c|c|c|c|c|}
\hline \multirow{2}{*}{ Indicator mark } & \multicolumn{11}{|c|}{ Competence coding symbol $(\mathrm{m}=11)^{\star}$} \\
\hline & $\mathrm{a}$ & $\mathrm{b}$ & c & $\mathrm{d}$ & e & $\mathrm{f}$ & g & $\mathrm{h}$ & $\mathrm{t}$ & $\mathrm{s}$ & $\mathrm{k}$ \\
\hline$\sum_{i=1}^{n} R_{i j}$ & 60 & 14 & 20 & 28 & 50 & 48 & 42 & 28 & 54 & 36 & 16 \\
\hline $\bar{R}_{j}=\frac{\sum_{i=1}^{n} R_{i j}}{n}$ & 10 & 2.3 & 3.3 & 4.7 & 8.3 & 8 & 7 & 4.7 & 9 & 6 & 2.7 \\
\hline$\sum_{i=1}^{n} R_{i j}-\frac{1}{2} n(m+1)$ & 24 & -22 & -16 & -8 & 14 & 12 & 6 & -8 & 18 & 0 & -20 \\
\hline$\left[\sum_{i=1}^{n} R_{i j}-\frac{1}{2} n(m+1)\right]^{2}$ & 576 & 484 & 256 & 64 & 196 & 144 & 36 & 64 & 324 & 0 & 400 \\
\hline
\end{tabular}

Note: Competence coding*: a - evaluate orders placed by clients; $\mathrm{b}$ - plan execution of orders; $\mathrm{c}$ - organize performance of orders; $\mathrm{d}$ - control order execution process; e - arrange loading and unloading of logistical product; $\mathrm{f}$ - store and control logistical product; $\mathrm{g}$ - manage stocks; $\mathrm{h}$ - organize packaging and dispatching processes of logistical product; $t$ - plan material flows in organization; $s$ - organize material flows in organization; $\mathrm{k}$ - control material flows in organization.

The concordance coefficient $W$ according to the formula (1) when there are no tied ranks was estimated.

$$
W=\frac{12 S}{n^{2}\left(m^{3}-m\right)}=\frac{12 \times 2544}{6^{2}\left(11^{3}-11\right)}=0.6424 .
$$

The number of important competencies for logistics managers $(m)$ is 11 , i.e., $m>7$. Thus, the concordance coefficient weight $\chi^{2}$ is estimated according to the formula (2) and a random variable is obtained.

$$
\chi^{2}=n(m-1) W=\frac{12 S}{n m(m+1)}=\frac{12 \times 2544}{6 \times 11(11+1)}=38.5454 .
$$

The estimated value of $\chi^{2}$ is 38,5454 , i.e., bigger than the critical value $\chi_{k r i t}{ }^{2}=18.307$, thus, the opinions of the respondents are considered to be concordant.

$$
W_{\text {min }}=\frac{\chi_{k r i t}^{2}}{n(m-1)}=\frac{18.307}{6(11-1)}=0.30512 .
$$

The smallest value of concordance coefficient $W_{\min }$ was estimated according to the formula (3). It is smaller than the concordance coefficient $W$, i.e., $0.30512<0.642424$, which illustrates the fact, that the opinions of all the six respondents about the criteria of the eleven competencies important for logistics managers are still regarded as concordant. 
The importance indicator $Q_{j}$ of the competencies important for logistics managers was estimated and all the competencies were ranked from the most to the least important (Table 3 ).

Table 3. The main indicators $Q_{j}$ of the important competencies for logistics managers (compiled by the authors)

\begin{tabular}{|l|c|c|c|c|c|c|c|c|c|c|c|c|}
\hline \multirow{2}{*}{$\begin{array}{l}\text { Indi- } \\
\text { cator } \\
\text { mark }\end{array}$} & \multicolumn{10}{|c|}{ Competence coding symbol $(\mathrm{m}=11)^{*}$} & \multirow{2}{*}{ Total } \\
\cline { 2 - 16 }$n$ & $\mathrm{a}$ & $\mathrm{b}$ & $\mathrm{c}$ & $\mathrm{d}$ & $\mathrm{e}$ & $\mathrm{f}$ & $\mathrm{g}$ & $\mathrm{h}$ & $\mathrm{t}$ & $\mathrm{s}$ & $\mathrm{k}$ & \\
\hline$q_{j}$ & 0.15 & 0.04 & 0.05 & 0.07 & 0.13 & 0.12 & 0.11 & 0.07 & 0.14 & 0.09 & 0.04 & 1 \\
\hline$d_{j}$ & 0.85 & 0.97 & 0.95 & 0.93 & 0.87 & 0.88 & 0.89 & 0.93 & 0.86 & 0.91 & 0.96 & 10 \\
\hline$Q_{j}$ & 0.09 & 0.10 & 0.10 & 0.09 & 0.09 & 0.09 & 0.09 & 0.09 & 0.09 & 0.09 & 0.10 & 1 \\
\hline$Q_{j}^{\prime}$ & 0.03 & 0.14 & 0.13 & 0.11 & 0.06 & 0.06 & 0.06 & 0.11 & 0.05 & 0.09 & 0.14 & 1 \\
\hline Ranks & 11 & 1 & 3 & 4.5 & 9 & 8 & 7 & 4.5 & 10 & 6 & 2 & \\
\hline
\end{tabular}

Note: Competence coding*: a - evaluate orders placed by clients; b - plan execution of orders; $\mathrm{c}$ - organize performance of orders; $\mathrm{d}$ - control order execution process; $\mathrm{e}$ - arrange loading and unloading of logistical product; $\mathrm{f}$ - store and control logistical product; $\mathrm{g}$ - manage stocks; $\mathrm{h}$ - organize packaging and dispatching processes of logistical product; $t$ - plan material flows in organization; $s$ - organize material flows in organization; $\mathrm{k}$ - control material flows in organization.

Based on the expert assessments, the following five highest-ranking competencies important for logistics managers were singled out: ability to plan execution of orders, control of material flows in organization, organizing performance of orders, control of order execution process, organizing packaging and dispatching processes of logistical products.

The experts were also asked to assess the most important competencies for logistics forwarders working in transport organizations ( 1 as the most important, 18, as the least important) (Figure 4).

Table 4 shows the questionnaire results on the importance of the competencies of logistics forwarders indicated by the six experts and the key estimated values: total rank, mean rank, the difference between total rank and rank constant and the square of variable (Table 4).

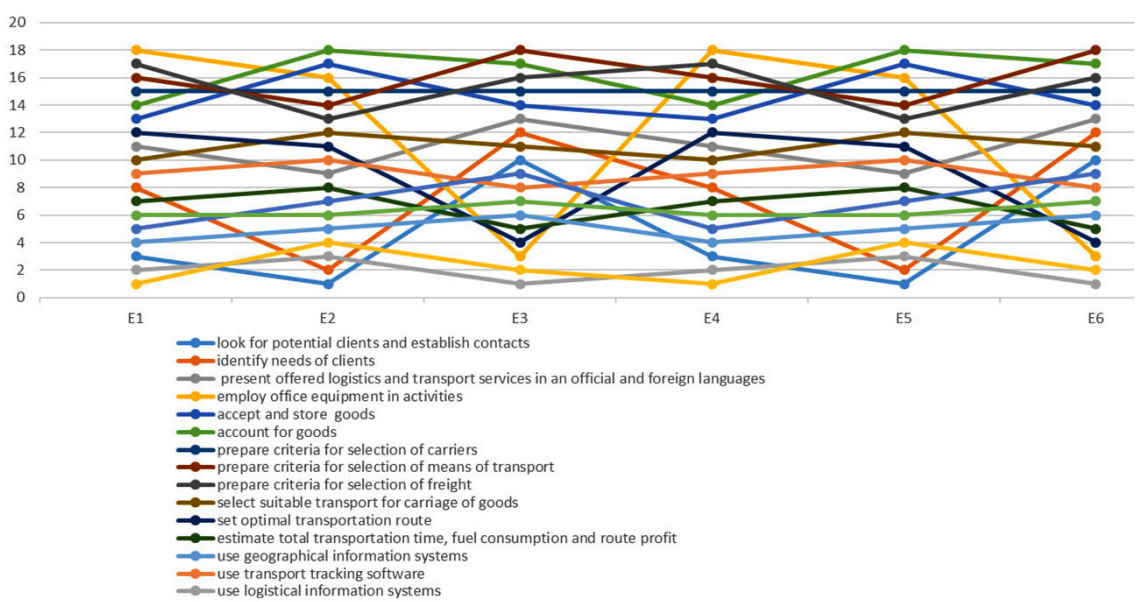

Figure 4. Distribution of competencies necessary for logistics forwarders after expert ranking (compiled by the authors) 


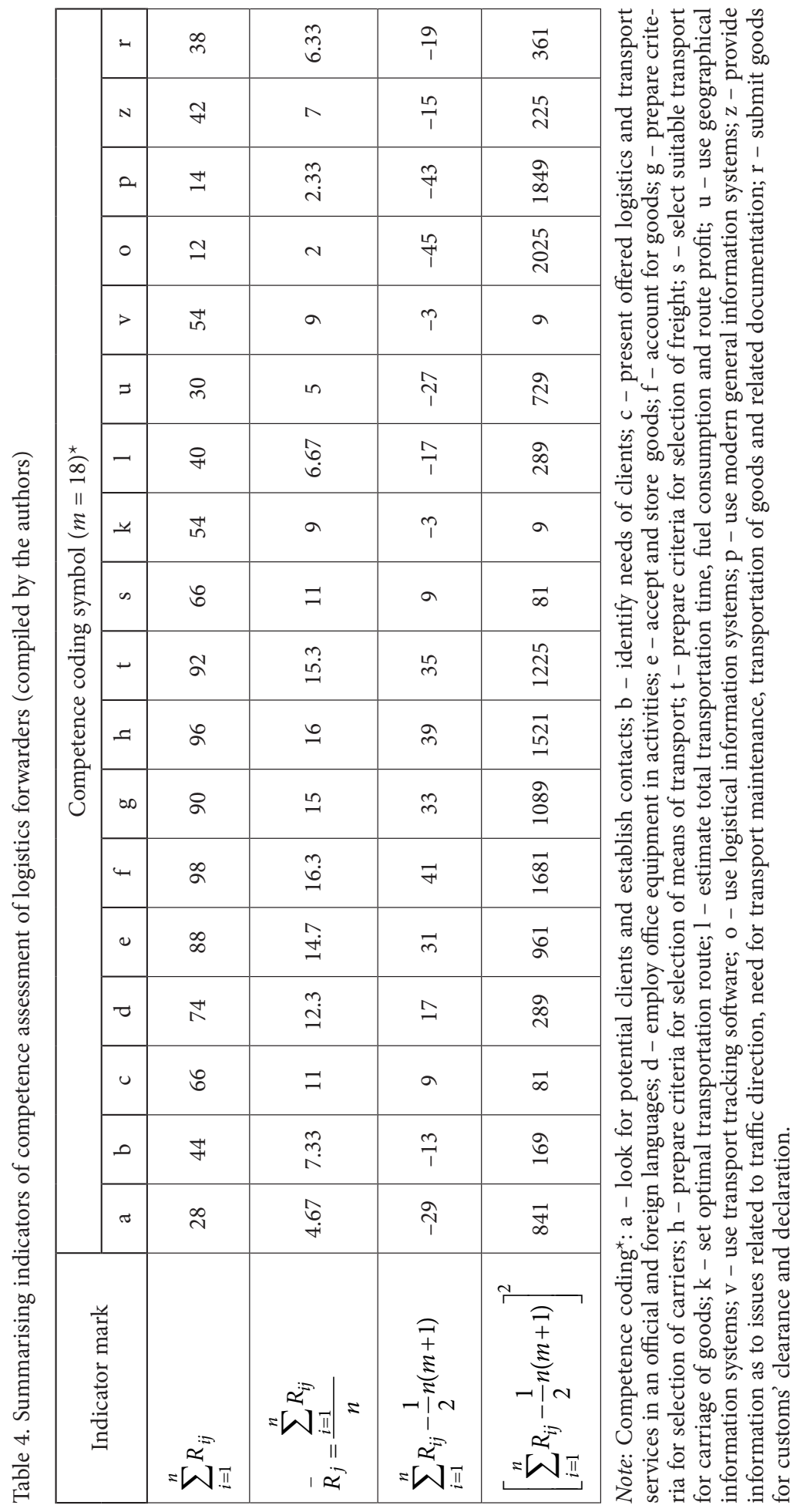


The concordance coefficient $W$, according to the formula (4), without tied ranks, was estimated.

$$
W=\frac{12 S}{n^{2}\left(m^{3}-m\right)}=\frac{12 \times 13434}{6^{2}\left(18^{3}-18\right)}=0.77021 .
$$

The number of important competencies for logistics forwarders $(m)$ is 18, i.e., $m>7$. Thus, the concordance coefficient weight $\chi^{2}$ is estimated according to the formula (5) and a random variable is obtained.

$$
\chi^{2}=n(m-1) W=\frac{12 S}{n m(m+1)}=\frac{12 \times 13434}{6 \times 18(18+1)}=78.5614
$$

The estimated value of $\chi^{2}$ is 78.5614 , i.e., bigger than the critical value $\chi_{k r i t}{ }^{2}=27.5871$, thus, the opinions of the respondents are considered to be concordant.

$$
W_{\min }=\frac{\chi_{k r i t}^{2}}{n(m-1)}=\frac{27.5871}{6(18-1)}=0.270462 \text {. }
$$

The smallest value of concordance coefficient $W_{\min }$ was estimated according to the formula (6). It is smaller than the concordance coefficient $W$, i.e., $0.270462<0.77021$, which illustrates that the opinions of all the six respondents about the criteria of the eighteen competencies important for logistics forwarders, are still regarded as concordant.

The importance indicator $Q_{j}$ of the competencies important for logistics forwarders was estimated, and all the competencies were ranked from the most to the least important (Table 5).

\begin{tabular}{|c|c|c|c|c|c|c|c|c|c|c|c|c|c|c|c|c|c|c|c|}
\hline \multirow{2}{*}{$\begin{array}{l}\text { Indi- } \\
\text { cator } \\
\text { mark }\end{array}$} & \multicolumn{19}{|c|}{ Competence coding symbol $(\mathrm{m}=18)^{*}$} \\
\hline & $\mathrm{a}$ & $\mathrm{b}$ & c & d & $\mathrm{e}$ & $\mathrm{f}$ & g & $\mathrm{h}$ & $\mathrm{t}$ & s & $\mathrm{k}$ & 1 & $\mathrm{u}$ & $\mathrm{v}$ & o & $\mathrm{p}$ & $\mathrm{z}$ & $\mathrm{r}$ & $\begin{array}{l}\text { To- } \\
\text { tal }\end{array}$ \\
\hline$q_{j}$ & 0.03 & 0.04 & 0.06 & 0.07 & 0.09 & 0.10 & 0.09 & 0.09 & 0.09 & 0.06 & 0.05 & 0.04 & 0.03 & 0.05 & 0.01 & 0.01 & 0.04 & 0.04 & 1 \\
\hline$d_{j}$ & 0.97 & 0.96 & 0.94 & 0.93 & 0.91 & 0.91 & 0.91 & 0.91 & 0.91 & 0.94 & 0.95 & 0.96 & 0.97 & 0.95 & 0.99 & 0.99 & 0.96 & 0.96 & 17 \\
\hline$Q_{j}$ & 0.06 & 0.06 & 0.06 & 0.06 & 0.05 & 0.05 & 0.05 & 0.05 & 0.05 & 0.06 & 0.06 & 0.06 & 0.06 & 0.06 & 0.06 & 0.06 & 0.06 & 0.06 & 1 \\
\hline$\overline{Q_{j}^{\prime}}$ & 0.08 & 0.07 & 0.05 & 0.04 & 0.03 & 0.02 & 0.02 & 0.02 & 0.02 & 0.05 & 0.06 & 0.07 & 0.08 & 0.06 & 0.10 & 0.10 & 0.07 & 0.07 & 1 \\
\hline Ranks & 3 & 8 & 11 & 13 & 14 & 18 & 15 & 17 & 16 & 12 & 9 & 6 & 4 & 10 & 1 & 2 & 7 & 5 & \\
\hline
\end{tabular}

Table 5. The main indicators $Q_{j}$ of the important competencies for logistics forwarders (compiled by the authors)

Note: Competence coding ${ }^{\star}: \mathrm{a}$ - look for potential clients and establish contacts; $\mathrm{b}$ - identify needs of clients; $\mathrm{c}$ - present offered logistics and transport services in an official and foreign languages; $\mathrm{d}$ - employ office equipment in activities; e - accept and store goods; f - account for goods; $\mathrm{g}$ - prepare criteria for selection of carriers; $\mathrm{h}$ - prepare criteria for selection of means of transport; $\mathrm{t}$ - prepare criteria for selection of freight; $\mathrm{s}$ - select suitable transport for carriage of goods; $\mathrm{k}$ - set optimal transportation route; 1 - estimate total transportation time, fuel consumption and route profit; $\mathrm{u}$ - use geographical information systems; $\mathrm{v}$ - use transport tracking software; $\mathrm{o}$ - use logistical information systems; $\mathrm{p}$ - use modern general information systems; $\mathrm{z}$ - provide information as to issues related to traffic direction, need for transport maintenance, transportation of goods and related documentation; $r$ - submit goods for customs' clearance and declaration. 
Based on the expert assessments, the following five highest-ranking competencies important for logistics forwarders were singled out: the ability to use logistical information systems, the ability to use modern general information systems, finding potential clients and establishing contacts, ability to use geographical information systems, submitting the goods for customs' clearance and declaration.

Deficiencies in the competence of logistics specialists working in transport organizations, and inconsistencies in their timely employment, reduce the efficiency of the functions performed and slow down the organization's business processes. In order to adapt to the changing market, and to increase the efficiency of the functions performed by the company, it is necessary to find out the excellence of the competencies of logistics specialists.

In addition, the experts were asked to assess (1 as the most important, 18, as the least important) the excellence of the competencies (the competencies used practically) of logistics specialists working in transport organizations when providing the related services.

The concordance of coefficient $W$ according to the formula (7) without tied ranks was estimated.

$$
W=\frac{12 S}{n^{2}\left(m^{3}-m\right)}=\frac{12 \times 10388}{6^{2}\left(18^{3}-18\right)}=0.5956 .
$$

The number of important competencies for logistics specialists $(m)$ is 18 , i.e., $m>7$. Thus, the concordance coefficient weight $\chi^{2}$ is estimated according to the formula (8) and a random variable is obtained.

$$
\chi^{2}=n(m-1) W=\frac{12 S}{n m(m+1)}=\frac{12 \times 10388}{6 \times 18(18+1)}=60.748
$$

The estimated value of $\chi^{2}$ is 60.748 , i.e., bigger than the critical value $\chi_{k r i t}^{2}=27.5871$, thus, the opinions of the respondents are considered to be concordant.

$$
W_{\min }=\frac{\chi_{k r i t}^{2}}{n(m-1)}=\frac{27.5871}{6(18-1)}=0.2704 \text {. }
$$

The smallest value of concordance coefficient $W_{\min }$ was estimated according to the formula (9). It is smaller than the concordance coefficient $W$, i.e., $0.270462<0.5956$, which illustrates that the opinions of all the six respondents about the criteria of the eighteen competencies important for logistics specialists are still regarded as concordant.

Having analyzed the obtained data, the following most important competencies mastered by logistics specialists were singled out: the aility to use geographical information systems, finding potential clients and establishing contacts, identifying the needs of clients, submitting goods for customs' clearance and declaration, and providing the information as to the issues related to traffic direction, the need for transport maintenance, transportation of goods and the related documentation.

The analysis of the research results revealed that the majority of the respondents $(83.33 \%)$ believe that in the future the attention by logistics specialists should be paid to the improvement of the special competencies, as this helps organizations to make logistical processes more efficient and logistics specialists to perform their work, i.e., to plan, organize and control various operations of a transport organization, or, at least, their cost. 


\section{Conclusions}

Having analyzed the concepts of competences by various scientists, it has been determined that a greater part of the scientists do not agree to the content of the concepts of competences and their application scope. Some authors claim that the concepts of competences are suitable solely to generalize knowledge, whereas, others believe that competences are only certain ways of operation that enable the achievement of the set goals. Still others are convinced that competences are a set of personal traits needed to perform a certain task. Taking into consideration the fact that the competences of logistics specialists are related to the ability to perform a specific assignment in the sphere of transport/logistics, the following definition of competences has been prepared: they are a set of personal abilities, skills and professional knowledge required and applied to perform the activities/functions/work of a particular type.

Having analyzed the content of the competencies necessary for logistics managers and logistics forwarders, the following key competence groups can be distinguished: special competencies (the competencies required for the work with people); analytical competencies (the competencies required for the performance of work); and personal competencies (selfmanagement competencies). These competencies are highly important for the increased efficiency in the work of logistics specialists and competitiveness of an organization.

The changes in the transportation market oblige organizations to constantly review the competencies of logistics specialists, to be able to assess them and identify the missing competencies. During the research, it has been determined that it is crucial for a logistics manager to be able to plan the execution of orders, to control the material flows within an organization, to organize the performance of orders, to control the order execution process, to organize the packaging and dispatching processes of logistical products; whereas, a logistics forwarder should be able to use logistical information systems, to manage modern general information systems, to find potential clients and to establish contacts, to use geographical information systems, and to submit goods for customs' clearance and declaration.

The analysis of the research results has revealed that is necessary to further improve the competencies of logistics specialists in transport organizations related to logistical information systems, i.e., appropriate attention should be paid to the improvement of special competencies.

\section{References}

Abraham, S. E., Karns, L. A., Shaw, K., \& Mena, M. A. (2001). Managerial competencies and the managerial performance appraisal process. Journal of Management Development, 20(10), 842-852. https://doi.org/10.1108/02621710110410842

Armesh, H., Wei, C. C., Ghalandarzehie, K., Sargolzaie, A., \& Kahrazeh, Y. (2014). Impact of organization and environment components on corporate entrepreneurship and firm performance: Mediating role of corporate entrepreneurship exploring on Literature Review. Journal of Basic \& Applied Scientific Research, 4(3), 113-124.

Bagaeva, I., Levina, A., \& Voronova, O. (2019, September). Formation of requirements to the competency model for a University Graduate in the digital economy. In Atlantis Highlights in Computer Sciences: Vol. 1. Proceedings of the International Conference on Digital Technologies in Logistics and Infrastructure (ICDTLI 2019) (pp. 333-338). Atlantis Press. https://doi.org/10.2991/icdtli-19.2019.58 
Besterfield-Sacre, M., Zappe, S., Shartrand, A., \& Hochstedt, K. (2016). Faculty and student perceptions of the content of entrepreneurship courses in engineering education. Advances in Engineering Education, 5(1), 4-28. https://advances.asee.org/wp-content/uploads/vol05/issue01/Papers/AEE-17-E-ship-Mary.pdf

Bondarenko, V., Diugowanets, O., \& Kurei, O. (2021, January). Transformation of managerial competencies within the context of global challenges. In SHS Web of Conferences (Vol. 90). 02002. EDP Sciences. https://doi.org/10.1051/shsconf/20219002002

Chlivickas, E., Papšienè, P., \& Papšys, A. (2009). Žmogiškieji ištekliai: strateginio valdymo aspektai [Human resources: Aspects of strategic management]. Verslas, vadyba ir studijos, 8(1), 51-65 (in Lithuanian). https://doi.org/10.3846/bme.2010.04

Chan, C. K., \& Luk, L. Y. (2020). Development and validation of an instrument measuring undergraduate students' perceived holistic competencies. Assessment \& Evaluation in Higher Education, 46(3), 467-482. https://doi.org/10.1080/02602938.2020.1784392

Devi, A., \& Goswami, G. (2014). Women enterpreneurship development in Assam with special reference to Kamurp district, India. The Clarion, International Multidisciplinary Journal, 3(1), 149-156.

Dobroszek, J., Mourao, P., \& Grzesiak, L. (2019). Identification of the similarities and differences of logistics controller, manager and specialist: A study based on a content analysis. The International Journal of Logistics Management, 30(1), 261-283. https://doi.org/10.1108/IJLM-10-2017-0281

Ekhtiari, M., Yadegari, E., \& Sadidi, G. (2016). Ranking enterpreneurship main risks in non-profit financial funds by Todim technique under grey conditions (a case study in Iran). Economic Computation \& Economic Cybernetics Studies \& Research, 50(3), 319-336. https://ideas.repec.org/a/cys/ecocyb/v50y2016i3p319-336.html

Erkutlu, H., \& Chafra, J. (2012). The impact of team empowerment on proactivity: The moderating roles of leader's emotional intelligence and proactive personality. Journal of Health Organization and Management, 26(5), 560-577. https://doi.org/10.1108/14777261211256918

European Logistics Association. (2014). http://www.elalog.eu/

Gutiérrez, A., R. C., \& Guerrero, A. B. (2012). Education and entrepreneurship: Educating in the new competence of autonomy and personal initiative. International Journal of Learning, 18(8), 237-247. https://doi.org/10.18848/1447-9494/CGP/v18i08/47705

Harreld, J. B., O’Reilly III, C. A., \& Tushman, M. L. (2007). Dynamic capabilities at IBM: Driving strategy into action. California Management Review, 49(4), 21-43. https://doi.org/10.2307/41166404

Jerman, A., Pejic Bach, M., \& Aleksic, A. (2020). Transformation towards smart factory system: Examining new job profiles and competencies. Systems Research and Behavioral Science, 37(2), 388-402. https://doi.org/10.1002/sres.2657

Jovaiša, T., Laužackas, R., Spūdytė, I., \& Tutlys, V. (2008). Lietuvos kvalifikaciju sistemos metodologija: monografija [Lithuanian qualifications system methodology. Monograph]. Lietuvos darbo rinkos mokymo tarnyba (in Lithuanian).

Juodeikaite, M., \& Fominienè, A. (2016). Žmogiškujjų išteklių valdymo procesų pokyčių vertinimas: teorinis ir praktinis aspektas [Assessment of changes in human resource management processes: Theoretical and practical aspects]. Informacijos mokslai, 74, 2537 (in Lithuanian). https://doi.org/10.15388/Im.2016.74.9920

Kilibarda, M., Pajić, V., \& Andrejić, M. (2019). Human resources in logistics and supply chains: Current state and trends. International Journal for Traffic and Transport Engineering, 9(3), 270-279. https://doi.org/10.7708/ijtte.2019.9(3).01

Kotzab, H., Teller, C., Bourlakis, M., \& Wünsche, S. (2018). Key competences of logistics and SCM professionals: The lifelong learning perspective. Supply Chain Management, 23(1), 50-64.

https://doi.org/10.1108/SCM-02-2017-0079 
Kvalifikacijų ir profesinio mokymo plètros centras. (2015). Transporto ir saugojimo paslaugu sektoriaus profesinis standartas [Professional standard in the transport and storage services sector] (in Lithuanian). http://www.esparama.lt/documents/10157/490675/2015_profesinis_standartas_transportas.pdf

Lamoureux, K. (2008). Competency management: Gateway to an integrated talent strategy. Bersin \& Associates Research Report, 1, 7-10.

Ledauskaitė, K. (2010). Transporto sektoriaus žmogiškuju ištekliu potencialo ekonominis vertinimas [Economic evaluation of human resources potential in the transport sector] [Doctoral dissertation]. Technika (in Lithuanian).

https://talpykla.elaba.lt/elaba-fedora/objects/elaba:1831728/datastreams/MAIN/content

Lim, J., Yoon, J., \& Kim, M. (2020). Analyzis of the educational needs related to, and perceptions of the importance of, essential job competencies among science and engineering graduates. Education Sciences, 10(4), 85. https://doi.org/10.3390/educsci10040085

López, R. R., Herrera, M. K. I. F., Gómez, E. A. M., \& Amaya, P. C. P. (2020). Knowledge and skills of a logistics manager required by the manufacturing industry of Ciudad Juárez. In Intelligent systems reference library: Vol. 166. Techniques, tools and methodologies applied to global supply chain ecosystems (pp. 109-127). Springer, Cham. https://doi.org/10.1007/978-3-030-26488-8_6

Martin, J. A. (2011). Dynamic managerial capabilities and the multi-business team: The role of episodic teams in executive leadership groups. Organization Science, 22(1), 118-140. https://doi.org/10.1287/orsc.1090.0515

Martinkienè, J. (2009). Vadybinių kompetencijų taikymas verslo praktinio mokymo firmoje [Application of managerial competencies in a business practical training firm]. Vadyba, 14(1), 79-87 (in Lithuanian). https://www.lituanistika.lt/content/24383

Martinkus, B., Neverauskas, B., \& Sakalas, A. (2002). Vadyba: specialistu rengimo kiekybinis ir kokybinis aspektas [Management: Quantitative and qualitative aspects of specialist training]. Technologija (in Lithuanian).

Melnikova, J., \& Trakšelys, K. (2016). Darbuotojų inovatyvumo ir kūrybiškumo kompetencijos ugdymo(si) principai [Principles of employee innovation and creativity competence development]. Holistinis mokymasis, 2, 21-30. https://www.vdu.lt/cris/handle/20.500.12259/35169

Morkvènas, R. (2010). Organizacijos žiniu potencialo vertinimas [Assessment of organizational knowledge potential] [Doctoral dissertation]. Vilnius Gediminas Technical University (in Lihuanian). https://oatd.org/oatd/record?record=oai\%5C\%3Aelaba.lt\%5C\%3ALT-eLABa-0001\%5C\%3AE.02\% 5C 2010\%5C D_20100619_142429-18701

Paiva, E. L. (2017). Coevolução e competências operacionais: Visão presente e oportunidades de pesquisas futuras. Revista Alcance, 24(2), 164-174. https://doi.org/10.14210/alcance.v24n2.p164-174

Palšaitis, R., Čižiūnienè, K., \& Vaičiūtè, K. (2016, May 12-13). Social competencies and perspectives of human resources in a logistics organization. In The $9^{\text {th }}$ International Scientific Conference "Business and Management 2016" (pp. 15-19). Technika. https://doi.org/10.3846/bm.2016.52

Podvezko, V. (2005). Agreement of expert estimates. Technological and Economic Development of Economy, 11(2), 101-107. https://doi.org/10.3846/13928619.2005.9637688

Sivilevičius, H. (2011). Application of expert evaluation method to determinate the importance of operating asphalt mixing plant quality criteria and rank correlation. The Baltic Journal of Road and Bridge Engineering, 6(1), 48-58. https://doi.org/10.3846/bjrbe.2011.07

Tan, K. C., Kannan, V. R., \& Narasimhan, R. (2007). The impact of operations capability on firm performance. International Journal of Production Research, 45(21), 5135-5156. https://doi.org/10.1080/00207540600871269

Trivellas, P., Kakkos, N., Blanas, N., \& Santouridis, I. (2015). The impact of career satisfaction on work performance in accounting firms. The mediating effect of general competencies. Procedia Economics and Finance, 33, 468-476. https://doi.org/10.1016/S2212-5671(15)01730-X 
Tūtlys, V., Kaminskienè, L., \& Pileičikas, G. (2015). Kompetenciju vertinimo užduočiu sudarymo metodika [Methodology for creating competency assessment tasks]. Kvalifikacijų ir profesinio mokymo plètros centras. https://www.kpmpc.lt/kpmpc/wp-content/uploads/akreditacija/Kompetenciju_vertinimo_uzduociu_sudarymo_metodika.pdf

Vaičiūte, K., Skirmantienè, J., \& Domanska, L. (2017). Assessment of transport specialists' competencies in transport/logistics companies. Procedia Engineering, 187, 628-634.

https://doi.org/10.1016/j.proeng.2017.04.423

Weinert, F. E. (2001). Concept of competence: A conceptual clarification. In D. S. Rychen \& L. H. Salganik (Eds.), Defining and selecting key competencies (pp. 45-65). Hogrefe \& Huber Publishers. https://psycnet.apa.org/record/2001-05275-003

Wu, S. J., Melnyk, S. A., \& Flynn, B. B. (2010). Operational capabilities: The secret ingredient. Decision Sciences, 41(4), 721-754. https://doi.org/10.1111/j.1540-5915.2010.00294.x

Zacharia, Z. G., Nix, N. W., \& Lusch, R. F. (2011). Capabilities that enhance outcomes of an episodic supply chain collaboration. Journal of Operations Management, 29(6), 591-603. https://doi.org/10.1016/j.jom.2011.02.001

Zaychenko, I., Smirnova, A., \& Kriukova, V. (2019). Application of digital technologies in human resources management at the enterprises of fuel and energy complex in the Far North. In Advances in intelligent systems and computing: Vol. 983. International Scientific Conference Energy Management of Municipal Facilities and Sustainable Energy Technologies EMMFT 2018 (pp. 321-328). Springer, Cham. https://doi.org/10.1007/978-3-030-19868-8_33

Zatta, F. N., Tambosi Filho, E., Campos, F. C. D., \& Freitas, R. R. (2019). Operational competencies and relational resources: A multiple case study. RAUSP Management Journal, 54(3), 305-320.

https://doi.org/10.1108/RAUSP-12-2018-0146 